\title{
INTERDEPENDENCE BETWEEN ATRIAL FIBRILATION AND HEART FAILURE
}

\author{
Tica Otilia Anca ${ }^{1}$, Tica Ovidiu², Rosan Larisa ${ }^{1}$, Pantea Vlad², Ignat Romanul Ioana ${ }^{2}$, \\ Sandor Mircea ${ }^{2}$, Sandor-Huniadi Anca ${ }^{2}$, Babes Katalin ${ }^{1,2}$, Popescu Mircea-Ioachim ${ }^{1,2}$ \\ ${ }^{1}$ County Emergency Clinical Hospital of Oradea, Cardiology Clinic \\ ${ }^{2}$ Faculty of Medicine and Pharmacy of Oradea \\ Corresponding author: Tica Ovidiu \\ Corresponding address: Oradea, no. 70 Anatole France Street, 410482 \\ e-mail: ovidiu.tica@gmail.com
}

\begin{abstract}
Atrial fibrillation (AF) is the most common rhythm disorder worldwide, becoming epidemic. Heart failure (HF) is a life-threatening disease and addressing it should be a priority. In this paper, we analyse recent progress on the relationship between HF and AF. The interdependence between $A F$ and HF has not been elucidated and therefore remains an area of interest for research. It is estimated that both the incidence of AF and HF will increase significantly in the next decades worldwide, there will be a significant problem for health systems in several countries. It remains imperative to urgently promote additional research on epidemiology, mechanisms and treatment of AF and HF.
\end{abstract}

Key words: arrhythmia, atrial fibrillation, heart failure, risk factors.

\section{Rezumat}

Fibrilația atrială (FA) reprezintă cea mai întâlnită tulburare de ritm la nivel mondial, evoluția ei devenind epidemică. IC reprezintă principala cauză de deces cardiovascular. În această lucrare, analizăm progresele recente privind relația dintre IC și FA. Interdependența dintre FA și IC nu a fost clarificată și, prin urmare, rămâne o zonă de interes de cercetare. Se estimează că atât incidența FA, cât și a IC vor crește semnificativ în următoarele decenii la nivel mondial, devenind o povară semnificativă pentru sistemele de sănătate din mai multe țări. Rămâne imperios necesar să se promoveze cercetări suplimentare privind epidemiologia, mecanismul și tratamentul FA și IC.

Cuvinte cheie: aritmie, fibrilație atrială, insuficiență cardiacă, factori de risc. 


\section{Introduction}

Atrial fibrillation (AF) and heart failure (HF) are among the most common cardiovascular diseases being considered true epidemics. $A F$ is the most common heart rhythm disorder encountered in current global medical practice, and often the two pathologies coexist with similar risk factors. When affecting in synchronicity, AF and HF have cumulative side effects, are associated with significantly increased morbidity and mortality, thus having a low prognosis. ${ }^{1,2}$

It is estimated that the prevalence of atrial fibrillation in developed countries is approximately $\mathbf{1 . 5 - 2 \%}$ of the general population. ${ }^{3}$ Currently, the average age for patients with this progressive disease is between 75 and 85 years; about one third of the paroxysmal AF episodes are completely asymptomatic, which means that the real numbers are much higher than estimated. ${ }^{4}$

Heart failure is also a common disease in cardiovascular pathology, either in acute or chronic form, representing the final stage of progression of cardiovascular disease. It is a clinical syndrome characterized by the inability of the heart to provide a cardiac flow corresponding to the oxygen requirement at normal tissues level under normal venous pressure. $^{5}$

Heart failure has a prevalence of approximately $2 \%$ in the general population, reaching a prevalence of more than $10 \%$ in patients over 65 years of age. ${ }^{6}$ More than $2 \%$ of all hospitalizations are due to decompensated HF, and re-admittance 6 months after discharge can reach up to $50 \%{ }^{7}$ $\mathrm{HF}$ is the only growing disease in developed countries due to aging population and prolonging the life of cardiac patients. ${ }^{8}$

Mortality after discharge of HF patients is $10.4 \%$ at one month, $22 \%$ at one year, and $42.3 \%$ at 5 years. Each rehospitalisation increases the mortality rate by another 20 $22 \%{ }^{9}$

\section{Determinism between AF and HF}

Heart failure and atrial fibrillation are often associated with, and their interdependence leads to mutually potentiating harmful effects according to numerous studies demonstrating this paradigm. The Framingham study demonstrated that once the HF is installed, the annual risk of developing $A F$ increases 5 times directly proportional to the NYHA class of HF and the associated pathology that may play an important role. ${ }^{10}$

Recent clinical studies have shown that $A F$ is an independent, extremely sensitive predictor for mortality of HF patients. However, there are studies that have attempted to suggest that in the presence of correct HF treatment, AF is no longer a 
predictor of mortality, but their study methodology is questionable and leaves room for subjective interpretations. ${ }^{11}$

The presence and severity of diastolic dysfunction appear to be a strong precursor of non-valvar atrial fibrillation (NVAF) in the elderly, with an independent relationship between the severity of diastolic dysfunction and the development of NVAF. ${ }^{12}$

$\mathrm{AF}$ can also be interpreted as a marker of $\mathrm{HF}$ decompensation and the presence of one increases the chances of the other. It is extremely important for the timeframe in which AF and HF develop, the interdependence and succession in this morbid association. ${ }^{13}$

Although the causal relationship between the two conditions has not been fully determined, their coexistence can be explained to some extent by the presence of common risk factors (age, hypertension, metabolic disorders, diabetes, obesity, chronic pulmonary disease, cardiomyopathy, cardiac valvar pathologies, ischemic and non-ischemic cardiac pathologies), but also behavioural factors (stress, smoking, alcohol or drug use). ${ }^{14}$

\section{AF and HF: cause or effect?}

Until recently considered a benign arrhythmia, AF generates a higher cost to society and a burden on the public health system due to the frequencies of extremely severe complications such as embolic events (embolic stroke, peripheral acute ischaemia, etc.) and congestive heart failure which leads to a severe deterioration in the quality of life. The major goals of AF treatment in $\mathrm{HF}$ are prevention of thromboembolic complications, cardiac frequency control, sinus rhythm conversion and maintenance, if possible, improvement of symptoms and improvement of the quality of life. AF may induce the progression of heart failure by increasing heart rate during rest and exaggerated heart rate response to exercise. These reduce the diastolic filling time, which leads to a decrease in cardiac output and an irregularity of the ventricular response. Reduction of left ventricular filling (LV) during short cycles is not completely compensated by increased fill over longer cycles. The loss of effective atrial contraction function contributes, even more importantly, to patients with diastolic dysfunction.

The physio-pathological mechanisms of AF in HF patients are complex and involve reentry, activity triggering and cardiac automatism. Therefore, it is unlikely that a treatment strategy targeting any of these mechanisms restores sinus rhythm. An antiarrhythmic drug rhythm control and electric conversion strategy in patients with $\mathrm{AF}$ and HF does not bring any benefit to a ventricular auricular control strategy, therefore catheter ablation is recommended for $A F$ and ventricular frequency control therapies (ablation of atrioventricular node with biventricular stimulation). These new therapies have emerged as alternative therapies to conventional rhythm and chiropractic control strategies. In-depth studies are required to validate these therapies for patients with $\mathrm{AF}$ and $\mathrm{HF}^{15}$

\section{Temporal relations between AF and HF}

Temporal relations between $\mathrm{AF}$ and $\mathrm{HF}$ were examined in a study of 1,470 patients with new-onset $\mathrm{AF}$ and HF (Framingham Heart Study). The average follow-up was 5.6 years after the occurrence of $A F$ and 4.2 years after the development of HF. Of the patients who had $A F, 26 \%$ had a previous diagnosis of HF, and the remaining $16 \%$ of patients later 
developed HF during the follow-up period. Of the patients who had HF, 24\% a had a previous diagnosis of $\mathrm{AF}$ and $17 \%$ later developed AF during the follow-up period. ${ }^{16}$

The association between $\mathrm{AF}$ and $\mathrm{HF}$ development was also analysed in a study of 3288 patients diagnosed with AF at the Mayo Clinic. ${ }^{17}$ A number of $24 \%$ of patients developed HF during an average follow-up of 6.1 years, with an incidence of 44 to 1,000 patient-years. An increase in HF incidence was observed shortly after the diagnosis of $\mathrm{AF}$, with $7.8 \%$ of cases occurring in the first 12 months and approximately 3\% / year thereafter. Only about $2 \%$ of $\mathrm{AF}$ patients developed $\mathrm{HF}$ in 5 years after the AF diagnosis. ${ }^{18}$

\section{Therapeutic considerations on AF and HF}

The major objectives of $\mathrm{AF}$ in $\mathrm{HF}$ are the prophylaxis of thromboembolic complications, cardiac frequency control, conversion and maintenance of sinus rhythm with classical or new therapeutic options (catheter ablation, atrioventricular node ablation and / or pacemaker implantation), relief of symptomatology (inhibitors of the axis renin - angiotensin - aldosterone) and increase in the quality of life.

Patients with AF or HF present a therapeutic challenge for doctors who need to balance the ventricular frequency control and restoring sinus rhythm.

It is a priority to ensure a target ventricular frequency in patients with HF and AF with medication to the detriment of sinus rhythm. ${ }^{19}$

Rhythm control strategies involve antiarrhythmic drugs or invasive procedures (catheter ablation or surgical intervention) that present a significant risk, but that can assure the maintenance of sinus rhythm. ${ }^{20}$

Recent studies take into consideration AF ablation. CASTLE-AF (Catheter Ablation versus Standard Conventional Treatment in patients with Left ventricular dysfunction and Atrial Fibrillation) is one of the first studies to show that ablation in AF increases the left ventricular ejection fraction (LVEF) at 5 years post-ablation.

The RACE-3 study (Routine Versus Aggressive Upstream Rhythm Control for Prevention of Early Atrial Fibrillation in Heart Failure) demonstrated that in patients with $A F$, strict control of classical risk factors (control of obesity, diabetes, hypertension) contributes significantly to maintaining the sinus rhythm.

HF-directed therapies can protect the heart against AF. Although restoration of sinus rhythm in patients with HF may provide clinical benefits, current studies have failed to demonstrate the clinical benefit of sinus rhythm over optimal ventricular control. 
Recent advances in catheter ablation therapies for $A F$ have been shown to be effective in well-selected patients with HF, resulting in significant improvement of cardiac function, symptoms and quality of life. ${ }^{15}$

The prognostic significance of $\mathrm{AF}$ in $\mathrm{HF}$ patients remains controversial because there is no consensus demonstrating that $\mathrm{AF}$ is an independent risk factor for adverse outcomes.

Although HF patient rehospitalisation is a marker of severity and prognosis, it cannot be used as a surrogate for mortality, especially since in the first few weeks after discharge, mortality and re-admittances do not have the same trend. ${ }^{21}$

\section{Conclusions}

$\mathrm{AF}$ and $\mathrm{HF}$ will be the most important points in cardiovascular disease management as well as in public health services because the incidence is increasing and it has been shown that these diseases are generating adverse events and implicitly consuming financial and human resources.

It remains imperative to promote further research on the epidemiology, mechanism, detection and treatment of $\mathrm{AF}$ and HF.

Proper management of these diseases requires reassessment of clinical guidelines and prevention programs by updating national and European clinical registries.

\section{Bibliography:}

1. Chugh SS, Roth Ga, Gillum Rf, Mensah Ga, Global burden of atrial fibrillation in developed and developing nations, Glob Heart, 2014; 1: 113119

2. Maisel Wh, Stevenson Lw, Atrial fibrillation in heart failure: epidemiology, pathophysiology, and rationale for therapy. AmJ Cardiol 2003; 6A: 2D-8D

3. Agency for Healthcare Research and Quality. Weighted national estimates. HCUP National Inpatient Sample, 2012
4. A.J Camm, G.YH Lip, R. De Caterina, et al., Actualizarea ghidului de management al fibrilației atriale al Societãții Europene de Cardiologie 2012, Romanian Journal of Cardiology, 2013, Vol. 23, No. 2, pg 66

5. C.W Yancy, M. Jessup, B. Bozkurt, et al., ACC/AHA/ICSA Focused Update of the 2013 ACCF/AHA Guideline for the Management of Heart Failure: A Report of the American College of Cardiology/American Heart Association Task Force on Clinical Practice Guidelines and the Heart Failure Society of America, Circulation, 2017, https://doi.org/10.1161/CIR.0000000000000509, Circulation. 2017;

6. MR Cowie, S.D. Anker, J.G.F. Cleland, et al., Improving care for patients with acute heart failure, 2014,Oxford PharmaGenesis, ISBN 978-1-903539-12-5. Available online at: http://www.oxfordhealthpolicy forum.org/reports/acute-heart-failure/improving-carefor-patients-with-acute-heart-failure

7. V.L Roger, 2013, Epidemiology of Heart Failure, Circulation Research. 2013; 113: 646-659 http://circres.ahajournals.org/content/113/6/646.full

8. A.L Bui, TB. Horwich, GC. Fonarow, Epidemiology and Risk Profile of Heart Failure, 2017, Nature reviews. Cardiology, 8.1 (2011): 30-41. PMC. Web.

9. V. L Roger, et al, 2011, Heart Disease and Stroke Statistics--2011 Update: A Report from the American Heart Association. Circulation 123, e18-e209 (2011)

10. K.L Kalon, L.Pinsky, W.B.Kannel, D.Levy, The epidemiology of heart failure: The Framingham Study, 1993, JACC Vol. 22. No. 4 (Supplement A) October 1 !893:6A43A https://www.ncbi.nlm. nih.gov/pubmed/ 8376698

11. SG Priori, C. Blomström-Lundqvist, A. Mazzanti, et al., Ghidurile ESC 2015 pentru managementul pacienţilor cu aritmii ventriculare şi prevenţia morţii subite cardiace Grupul Operativ pentru managementul pacienţilor cu aritmii ventriculare şi prevenţia morţii subite cardiace al Societăţii Europene de Cardiologie (ESC), Romanian Journal of Cardiology, Vol. 26, No. 4, 2016

12. Ts Tsang, Bj Gersh, Cp Appleton,et al., Left ventricular diastolic dysfunction as a predictor of the first diagnosed nonvalvular atrial fibrillation in 840 elderly men and women, J Am Coll Cardiol, 2002; 9: 1636-1644.

13. YM Cha, MM Redfield, WK Shen, BJ Gersh, et al., Atrial fibrillation and ventricular dysfunction: a vicious electromechanical cycle,2014, Circulation; 109:2839.

14. F Buccelletti, Di Somma S, lacomini $P$, et al., Assessment of baseline characteristics and risk factors among Emergency Department patients presenting with recent onset atrial fibrillation: a retrospective cohort study, 2014, Eur Rev Med Pharmacol Sci 2013; 17 


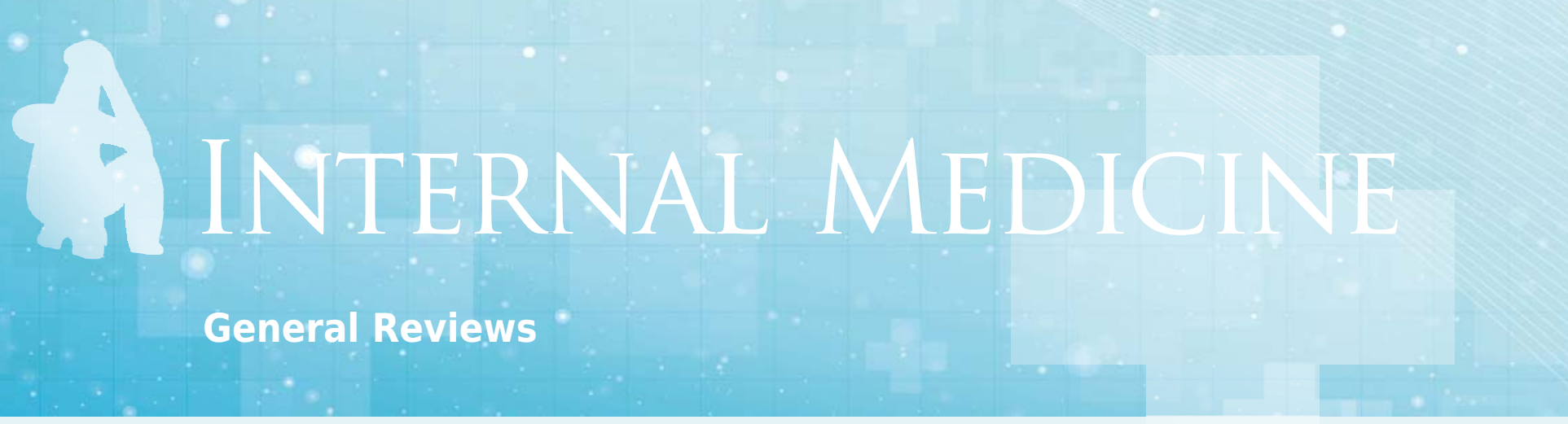

Suppl 1: 22

15. C.-Y. Hu, C.-Y. Wang, J.-Y. Li, J. Ma, Z.-Q. Li, Relationship between atrial fibrillation and heart failure, 2016; 20: 4593-4600, European Review for Medical and Pharmacological Sciences, http://www.europeanreview. org/wp/wp-content/uploads/4593-4600-Relationshipbetween-atrial-fibrillation-and-heart-failure.pdf

16. TJ Wang, MG Larson, D Levy, et al., Temporal relations of atrial fibrillation and congestive heart failure and their joint influence on mortality: the Framingham Heart Study, EJ Circulation, 2003 Jun 17; 107(23):2920-5

17. Y Miyasaka, Barnes ME, Gersh BJ, et al., Incidence and mortality risk of congestive heart failure in atrial fibrillation patients: a community-based study over two decade, Eur HeartJ., 2006 Apr; 27(8):936-41

18. Lubitz, Steven A., Emelia J. Benjamin, Patrick T.
Ellinor, Atrial Fibrillation in Congestive Heart Failure, Heart failure clinics, 6.2 (2010): 187-200. PMC. Web. 12 Nov. 2017

19. Chatterjee S, Sardar P, Lichstein E, Mukherjee D, Aikat S., Pharmacologic rate versus rhythm-control strategies in atrial fibrillation: an updated comprehensive review and meta-analysis. Pacing Clin Electrophysiol 2013; 1: 122-133.

20. Tadros R, Khairy P, Rouleau Jl, Talajic M, Guerra Pg, Roy $D$, Atrial fibrillation in heart failure: drug therapies for rate and rhythm control, Heart Fail Rev 2014; 3: 315 324.

21. Heidenreich PA, Sahay A, Kapoor JR, Pham MX, Massie $B$, Divergent trends in survival and readmission following a hospitalization for heart failure in the Veterans Affairs health care system 2002 to 2006, J Am Coll Cardiol. 2010; 56:362-368 